\title{
Review on Fracture, Dislocation and Neurological Affections in Animals between April 2011 to March 2013 around the Urban and Suburban Area of Guwahati, India
}

\author{
Chandan Kumar Singh", Kushal Konwar Sarma, Dwijen Kalita, \\ Bitupona Deuri and Parsha Jyoti Nath
}

\author{
Department of Veterinary Surgery and Radiology, College of Veterinary Science, Khanapara, \\ Assam Agricultural University, India \\ *Corresponding author
}

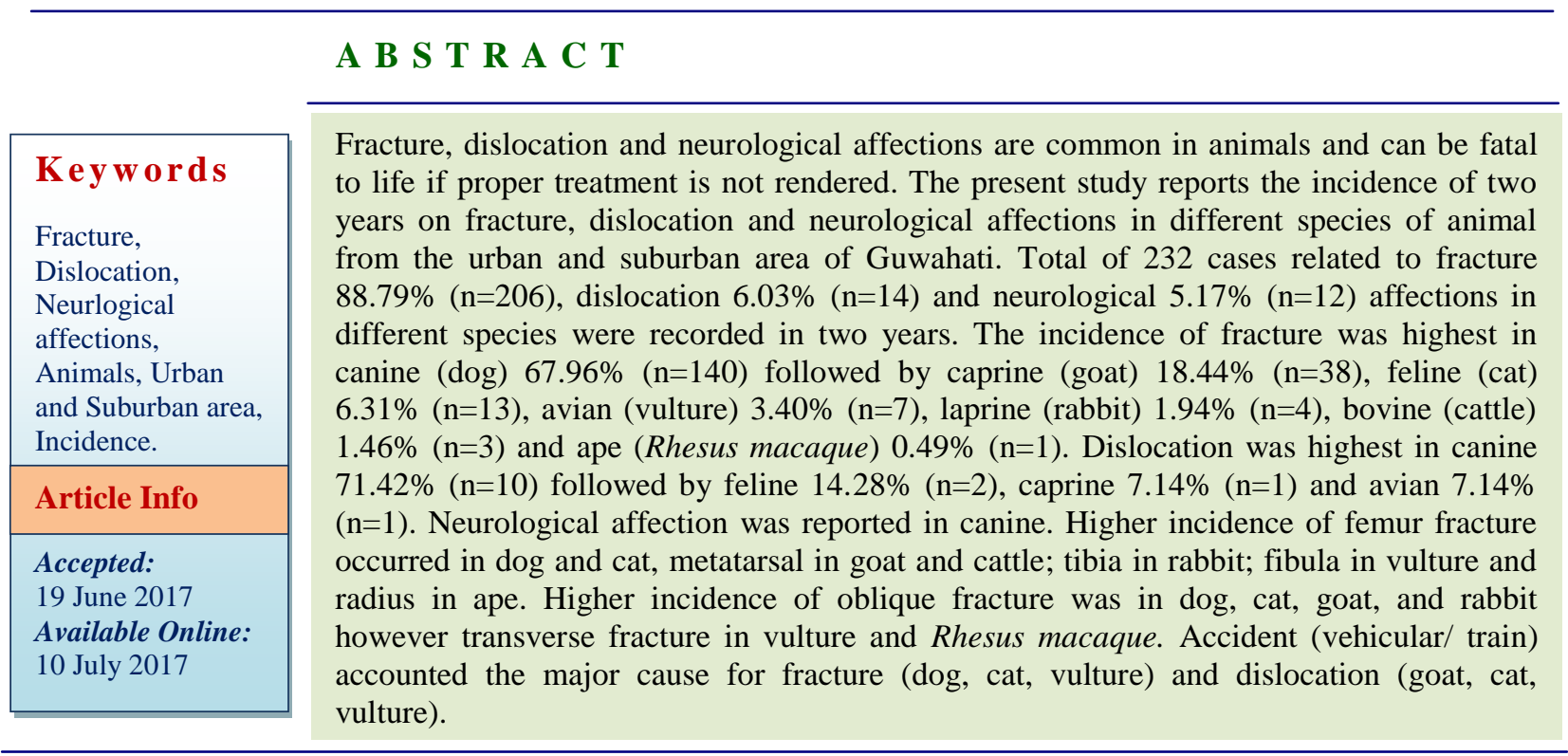

\section{Introduction}

Availability of information or data regarding various affections forms a powerful tool in terms of rendering appropriate treatment, saving times and economy, are beneficial for making better future policy and also reduces the loss of life and economy in near future. At present era it is challenging for the policy maker to come up with the policy in which animal and human requirement are kept equilibrium. In veterinary practices, the incidence of fracture has increased manifold (Aithal et al., 1999). The cause of increase in incidence is attributed to the increase in the number of automobile vehicles leading to motor vehicular accident, change in the life style of human as well as animal. Similar is the situation for dislocation and neurological affection where change in the life style of the humans has predisposed the animals towards these affections. Dogs due to their active nature often suffer from lameness (Mohsina et al., 2014). Lameness in dog is mainly due to musculoskeletal disorder though neurological cause cannot be ruled out (Scott and Witte, 
2011). Treatment of fracture, dislocation and neurological affections becomes challenging or irreparable when the conditions become chronic in nature. With the change of time, advancement in the treatment of fracture from intramedullary pin (Hulse and Aron, 1994) to interlocking nail (Muir and Johanson, 1996) to minimal invasive technique of plating and interlocking nail has evolved. The improvement in treatment of dislocation and neurological affections has also evolved in the recent period of time with the advancement of diagnostic modality in veterinary field. Data regarding incidence of fracture, dislocations and neurological affection from the corridor of North Eastern State of India are not available till date. Therefore the present study was designed to acquire data on fracture, dislocation and neurological affections from the urban and suburban area of Guwahati, Assam, India. This study will act as a base for the policy maker of the Northeastern part of India for implementation of future project in the field of orthopaedics and neurological affections in different species of animals.

\section{Materials and Methods}

All the registered fracture, dislocation and neurological affections cases in the Department of Veterinary Surgery and Radiology and Teaching Veterinary Clinical Complex, College of Veterinary Science, Khanapara, Assam Agricultural University for a period of two year from $1^{\text {st }}$ April 2011 to $31^{\text {st }}$ March 2013 were taken into study. Diagnosis was based on the clinical history, clinical sign, clinical examination, neurological examination, confirmation by radiograph and contrast radiography by using Iohexol. Treatment as medicinal or surgical interventions was provided wherever feasible. The data in respect of species, breed, sex, age, bone/ joint wise, loss of skin integrity, type of fracture, type of dislocation and cause were compiled and analysed.

\section{Results and Discussion}

A total number of 232 cases were recorded, related to fracture $(n=206)$, dislocation $(n=14)$ and neurological $(n=12)$ affections in different species in two years (Fig. 1). Fracture accounted highest $88.79 \%(\mathrm{n}=206)$ followed by dislocation $6.03 \%(\mathrm{n}=14)$ and neurological affection $5.17 \% \quad(n=12) \quad$ (Fig. 2). The incidence of fracture was highest in canine (dog) $67.96 \% \quad(n=140)$ followed by caprine (goat) $18.44 \% \quad(n=38)$, feline (cat) $6.31 \%$ $(\mathrm{n}=13)$, avian (vulture) $3.40 \%(\mathrm{n}=7)$, laprine (rabbit) $1.94 \%(\mathrm{n}=4)$, bovine (cattle) $1.46 \%$ $(\mathrm{n}=3)$ and ape (Rhesus macaque) $0.49 \%(\mathrm{n}=1)$ (Fig. 2). The higher incidence of fracture in canine $(\operatorname{dog})$ can be attributed to the species preference by the urban and suburban population of Guwahati as their companion pet. However it also depicts the sensitivity of the pet owners for availing medical treatment for their pets. The maximum incidence in canine (dog) might also be due to the higher number of motor vehicular accidents in this species of animal in comparison to the other species as they are let loose or due to their wandering habit which makes them more prone to accidents. The findings correlates with that of Tambe et al., (2012) where the authors observed highest incidence of fracture in dogs $(26.50 \%)$ followed by cattle $(25.20 \%)$, camels $(15 \%)$, buffaloes $(12.50 \%)$, horses $(8 \%)$, goats $(5.50 \%)$, birds $(4.50 \%)$, rabbits $(1.50 \%)$ and monkeys (1\%).

Dislocation was observed in 14 cases in different species (Fig. 3). In canine highest number of cases $71.43 \%(n=10)$ followed by feline $14.29 \%(n=2)$, caprine $7.14 \%(n=1)$ and avian $7.14 \%(\mathrm{n}=1)$ (Fig. 3). Mohsina et al., (2014) in their study on incidence of lameness in different species observed hip dislocation $(6 \%)$ as a cause of lameness in dogs. Neurological affection was observed only in canine $(\mathrm{n}=12)$ (Table 2). Mohsina et al., (2014) has opined that dogs often suffer from lameness due to their active nature. Scott and 
Witte (2011) have stated that lameness in dog occur more commonly due to musculoskeletal disorder than neurological.

The populations of swine (pig) are more in the suburban area of Guwahati however no cases on orthopaedic/dislocation/neurological affections were reported in swine (pig). This might be because of fewer occurrences of orthopaedic/dislocation/neurological affections in swine or might be because of the economic factor as the farmers prefer to slaughter their animal than taking the economic burden of treatment.

Fractures accounted for $67.96 \% \quad(n=140)$ cases in canine (dogs). The breed wise distribution of incidence of fracture revealed highest in Mongrel 52.14\% ( $\mathrm{n}=73)$ followed by Labrador $16.43 \%(\mathrm{n}=23)$, Spitz $10.71 \%$ $(\mathrm{n}=15)$, Dalmatian $5.71 \% \quad(\mathrm{n}=8)$, German shepherd $3.57 \%(\mathrm{n}=5)$, Lhasa Apso $1.43 \%$ $(n=2)$, Dobberman $2.14 \%(n=3)$, Rottweiler $(2.14 \%)(n=3)$, French Mastiff $1.43 \%(n=2)$, Pug $1.43 \%(\mathrm{n}=2)$, Daschund $1.43 \%(\mathrm{n}=2)$ and St. Bernard $1.43 \%(n=2)$ (Fig. 4). The highest incidences of fracture in Mongrel dogs might be due to their higher population size, being let loose and their wandering nature. The findings correlate to that of Aithal et al., (1999), Simon et al., (2010), Singh et al., (2011), Rani et al., (2007) however contrary to Balagopalan et al., (1995) where the highest incidence was observed in Alsatian breed.

The incidence of fracture was higher in male $\operatorname{dog} 66.43 \%(n=93)$ than the female $33.57 \%$ $(n=47)$ (Table 1). The higher incidence in male in the present study might be due to the higher population of male or male are preferred more as companion pet than the female in the area of study. This might also be attributed to the fact that the males are more aggressive and tend to wander more than female counterpart thus more vulnerable to road traffic accident, fall/jump (Kolata et al.,
1974). The findings in the present study correlate with that of Balagopalan et al., (1995), Aithal et al., (1999), Rani et al., (2007), and Simon et al., (2010).

Dog less than one year of age $54.29 \%(n=76)$ were affected more with fracture than above one year $45.71 \%(n=64)$ of age (Table 1$)$. This might be due to the fact that the young animals are more active and have not learnt to cope with the hazard unlike their older counterparts (Kolata et al., 1974) and might become nervous or excited on seeing motor vehicles therefore become more prone to accident.

Bone wise incidence of 140 fracture cases revealed, femur being mostly affected $35.71 \%$ $(\mathrm{n}=50)$, followed by radius $20 \%(\mathrm{n}=28)$, tibia $16.43 \%(n=23)$, humerus $8.57 \% \quad(n=12)$, metacarpal $5 \%(n=7)$, lumbar $4.29 \%(n=6)$, mandible $3.57 \%(\mathrm{n}=5)$, phalanges $3.57 \%$ $(n=5)$, metatarsal $2.86 \% \quad(n=4)$ (Table 1 and Fig. 5). The higher incidence of femur fracture might be due to the increased forces and momentum placed on proximal bones caused by physical factors such as muscle forces used for locomotion and resistance to the forces of gravity, ground reaction forces as limbs strike the ground and a long moment arm at the proximal aspect of limb compared with the distal portion of the limb (Markel et al., 1994). The findings agree with the previous studies (Simon et al., 2010; Aithal et al., 1999; Balagopalan et al., 1995; Patil et al., 1991). Closed fracture were recorded higher $58.57 \%(n=82)$ as compared to open fracture $41.43 \% \quad(n=58) \quad$ (Table 1). Higher incidence of closed fracture can be attributed to the fact that fracture incurred in higher percentage in the bone which were under the thick belly of muscle preventing them to lose its integrity through skin. The oblique fracture accounted highest $37.14 \%(n=52)$ followed by transverse $32.86 \% \quad(\mathrm{n}=46)$, spiral $13.57 \%$ $(\mathrm{n}=19)$, comminuted $5.71 \%(\mathrm{n}=8)$, multiple $10.71 \%(n=15)$ respectively (Table 1$)$. The 
higher incidence of oblique fracture may be attributed to the predominance of bending or compression force (Newton and Nunamaker, 1985) acting to break a dog's bone. The findings correlate with that of Aithal et al., (1999). Road traffic accident accounted for $61.43 \%(n=86)$ and due to fall or jump $38.57 \%(n=54)$ cases. The major causes of fracture in dogs were due to road traffic accident and correlates with the previous study by Mala and cello, (1975), Philips (1979), Aithal et al., (1999).

Dislocation was observed in 10 cases in canine (dog) (Table 2). Among the dislocation Coxo-femoral dislocation were observed in $70 \%(n=7)$, Lumbar dislocation $20 \%(n=2)$ and Scapulo-humeral 10\% $(\mathrm{n}=1)$ (Table 2). In Coxo-femoral dislocation $(n=7)$, cranio-dorsal coxo-femoral dislocation were observed in $71.43 \%(\mathrm{n}=5)$ and caudo-dorsal in $28.57 \%$ $(n=2)$ (Table 2). Coxo-femoral dislocation (cranio-dorsal dislocation) occurrence was higher than other dislocation and correlates with Newton and Nunamaker (1985). In lumbar dislocation $(\mathrm{n}=2), \quad \mathrm{L} 3-\mathrm{L} 4$ was observed in $50 \%(\mathrm{n}=1)$ and L4-L5 in $50 \%(\mathrm{n}=$ 1) (Table 2). In Scapulo-humeral $(n=1)$, medial scapulo-humeral dislocation was recorded in $100 \%(\mathrm{n}=1)$ (Table 2). Among the breed dislocation was accounted highest in Labrador $50 \% \quad(n=5) \quad$ (coxo-femoral) followed by German shepherd $20 \% \quad(n=2)$ (coxo-femoral), mongrel 20\% $(\mathrm{n}=2)(\mathrm{L} 3-\mathrm{L} 4$, L4-L5) and pug $10 \% \quad(\mathrm{n}=1) \quad$ (Scapulohumeral). The higher incidence in labrador breed might be due to the breed favoritism as companion pet or higher population of this breed in the area of study. Male dogs were affected more $70 \%(\mathrm{n}=7)$ in comparison to the females $30 \%(n=3)$ (Table 2). This might be because of the favoritism of male dogs as companion pet or due to their wandering habit which make them more vulnerable to accidents/fall/hit in the area of study. Higher incidence of dislocation was observed in dogs less than one year of age $60 \% \quad(n=6)$ than above one years of age $40 \%(n=4)$ (Table 2). This might be because as the joints of these dogs are in growing stage therefore trauma of any form may predispose them to dislocation. In the dogs with dislocation the most common cause was fall from height $50 \% \quad(n=5)$ followed by slipping on the marble floor $30 \%$ $(n=3)$ and vehicular accident by the owner $20 \%(n=2)$.

Neurological affection was reported in 12 cases (Fig. 1). Neurological affections were observed in Daschund $25 \% \quad(n=3)$, Dobberman $25 \% \quad(n=3)$, German shepherd $25 \%(n=3)$, Spitz $16.67 \%(n=2)$ and Labrador $8.33 \% \quad(n=1) . \quad$ Neurological affection accounted higher incidence in female $66.67 \%$ $(n=8)$ than male $33.33 \% \quad(n=4)$. The neurological affections accounted higher in animal above 1 year of age $75 \% \quad(n=9)$ followed by below one year of age $25 \%(n=3)$ (Table 2). The findings indicate that with the advancement of age the chance of neurological affections increases. Epilepsy was noted in $25 \%(n=3)$ cases followed by Vestibular syndrome $25 \% \quad(n=3)$, Intervertebral disk disease $16.66 \% \quad(\mathrm{n}=2)$, Wobbler syndrome $16.66 \% \quad(n=2)$, facial nerve paralysis $16.66 \%(\mathrm{n}=2)$ (Table 2$)$.

In Caprine (Goat) 38 cases of fracture were recorded (Fig. 2). Out of 38 recorded cases, 84.21\% $(n=32)$ cases were recorded in Assam hill goat followed by Black Bengal $13.16 \%$ $(n=5)$, beetal $2.63 \%(n=1)$ breed of goats (Fig. 2). The higher incidence in Assam hill goat might be because of the breed preference or readily availability and or disease resistant trait of this breed in the area of study. Fracture accounted highest in female $76.32 \%$ $(n=29)$ followed by male $23.68 \% \quad(n=9)$ (Table 1). This can be attributed to the fact that female goats are preferred by farmers due to their economic contribution, and the farmers are willing to take the burden of medical treatment in female goat. 
Table.1 Incidence of fracture, type of fracture, loss of integrity to the skin, Bone involved, sex and age in different species

\begin{tabular}{|c|c|c|c|c|c|c|c|}
\hline TYPE OF FRACTURE & $\begin{array}{c}\text { Canine } \\
\text { (Dog) }\end{array}$ & $\begin{array}{l}\text { Caprine } \\
\text { (Goat) }\end{array}$ & $\begin{array}{c}\text { Feline } \\
\text { (Cat) }\end{array}$ & $\begin{array}{c}\text { Avian } \\
\text { (Vulture) }\end{array}$ & $\begin{array}{l}\text { Laprine } \\
\text { (Rabbit) }\end{array}$ & $\begin{array}{l}\text { Bovine } \\
\text { (Cattle) }\end{array}$ & $\begin{array}{c}\text { Ape } \\
\text { (Monkey) }\end{array}$ \\
\hline Oblique & $\begin{array}{l}37.14 \% \\
(\mathrm{n}=52)\end{array}$ & $\begin{array}{l}31.58 \% \\
(\mathrm{n}=12)\end{array}$ & $\begin{array}{c}61.54 \% \\
(\mathrm{n}=8)\end{array}$ & $\begin{array}{c}14.29 \% \\
(\mathrm{n}=1)\end{array}$ & $\begin{array}{l}50 \% \\
(\mathrm{n}=2)\end{array}$ & $\begin{array}{l}0 \\
0 \\
\end{array}$ & $\begin{array}{l}0 \\
0\end{array}$ \\
\hline Transverse & $\begin{array}{c}32.86 \% \\
(\mathrm{n}=46)\end{array}$ & $\begin{array}{c}26.31 \% \\
(\mathrm{n}=10)\end{array}$ & $\begin{array}{c}23.08 \% \\
(\mathrm{n}=3)\end{array}$ & $\begin{array}{c}28.57 \% \\
(\mathrm{n}=2)\end{array}$ & $\begin{array}{l}25 \% \\
(\mathrm{n}=1)\end{array}$ & $\begin{array}{c}33.33 \% \\
(\mathrm{n}=1)\end{array}$ & $\begin{array}{l}100 \% \\
(\mathrm{n}=1)\end{array}$ \\
\hline Spiral & $\begin{array}{l}13.57 \% \\
(\mathrm{n}=19)\end{array}$ & $\begin{array}{c}15.80 \% \\
(\mathrm{n}=6)\end{array}$ & $\begin{array}{c}15.38 \% \\
(\mathrm{n}=2)\end{array}$ & $\begin{array}{c}28.57 \% \\
(\mathrm{n}=2)\end{array}$ & $\begin{array}{l}25 \% \\
(\mathrm{n}=1)\end{array}$ & $\begin{array}{l}0 \\
0\end{array}$ & $\begin{array}{l}0 \\
0\end{array}$ \\
\hline Comminuted & $\begin{array}{c}5.71 \% \\
(\mathrm{n}=8)\end{array}$ & $\begin{array}{l}0 \\
0\end{array}$ & $\begin{array}{l}0 \\
0\end{array}$ & $\begin{array}{l}0 \\
0\end{array}$ & $\begin{array}{l}0 \\
0\end{array}$ & $\begin{array}{l}0 \\
0\end{array}$ & $\begin{array}{l}0 \\
0\end{array}$ \\
\hline Multiple & $\begin{array}{l}10.71 \% \\
(\mathrm{n}=15)\end{array}$ & $\begin{array}{c}26.30 \% \\
(\mathrm{n}=10)\end{array}$ & $\begin{array}{l}0 \\
0\end{array}$ & $\begin{array}{c}28.57 \% \\
(\mathrm{n}=2)\end{array}$ & $\begin{array}{l}0 \\
0\end{array}$ & $\begin{array}{c}66.67 \% \\
(\mathrm{n}=2)\end{array}$ & $\begin{array}{l}0 \\
0\end{array}$ \\
\hline \multicolumn{8}{|l|}{$\begin{array}{c}\text { LOSS OF INTEGRITY } \\
\text { TO THE SKIN } \\
\end{array}$} \\
\hline $\begin{array}{l}\text { Compound/Open } \\
\text { fracture }\end{array}$ & $\begin{array}{l}41.43 \% \\
(\mathrm{n}=58)\end{array}$ & $\begin{array}{l}57.89 \% \\
(\mathrm{n}=22)\end{array}$ & $\begin{array}{c}46.15 \% \\
(\mathrm{n}=6)\end{array}$ & $\begin{array}{c}71.43 \% \\
(\mathrm{n}=5)\end{array}$ & $\begin{array}{l}50 \% \\
(\mathrm{n}=2)\end{array}$ & $\begin{array}{l}100 \% \\
(\mathrm{n}=3)\end{array}$ & $\begin{array}{l}0 \\
0\end{array}$ \\
\hline Closed fracture & $\begin{array}{l}58.57 \% \\
(\mathrm{n}=82)\end{array}$ & $\begin{array}{l}42.11 \% \\
(\mathrm{n}=16)\end{array}$ & $\begin{array}{c}53.85 \% \\
(\mathrm{n}=7)\end{array}$ & $\begin{array}{c}28.57 \% \\
(\mathrm{n}=2)\end{array}$ & $\begin{array}{l}50 \% \\
(\mathrm{n}=2)\end{array}$ & $\begin{array}{l}0 \\
0 \\
\end{array}$ & $\begin{array}{l}100 \% \\
(\mathrm{n}=1)\end{array}$ \\
\hline \multicolumn{8}{|l|}{$\begin{array}{l}\text { BONE WISE } \\
\text { FRACTURE }\end{array}$} \\
\hline Femur & $\begin{array}{c}35.71 \% \\
(\mathrm{n}=50)\end{array}$ & $\begin{array}{c}2.63 \% \\
(\mathrm{n}=1)\end{array}$ & $\begin{array}{c}46.15 \% \\
(\mathrm{n}=6)\end{array}$ & $\begin{array}{c}14.29 \% \\
(\mathrm{n}=1)\end{array}$ & $\begin{array}{l}25 \% \\
(\mathrm{n}=1)\end{array}$ & $\begin{array}{l}0 \\
0\end{array}$ & $\begin{array}{l}0 \\
0\end{array}$ \\
\hline Radius & $\begin{array}{c}20 \% \\
(\mathrm{n}=28)\end{array}$ & $\begin{array}{c}10.52 \% \\
(\mathrm{n}=4)\end{array}$ & $\begin{array}{l}0 \\
0\end{array}$ & $\begin{array}{c}28.57 \% \\
(\mathrm{n}=2) \\
\text { (Ulna) }\end{array}$ & $\begin{array}{l}25 \% \\
(\mathrm{n}=1)\end{array}$ & $\begin{array}{l}0 \\
0\end{array}$ & $\begin{array}{l}100 \% \\
(\mathrm{n}=1)\end{array}$ \\
\hline Tibia & $\begin{array}{l}16.43 \% \\
(\mathrm{n}=23)\end{array}$ & $\begin{array}{c}18.42 \% \\
(\mathrm{n}=7)\end{array}$ & $\begin{array}{c}30.77 \% \\
(\mathrm{n}=4)\end{array}$ & $\begin{array}{c}42.85 \% \\
(\mathrm{n}=3) \\
(\text { Fibula) }\end{array}$ & $\begin{array}{l}50 \% \\
(\mathrm{n}=2)\end{array}$ & $\begin{array}{l}0 \\
0\end{array}$ & $\begin{array}{l}0 \\
0\end{array}$ \\
\hline Humerus & $\begin{array}{l}8.57 \% \\
(\mathrm{n}=12)\end{array}$ & $\begin{array}{l}5.26 \% \\
(\mathrm{n}=2)\end{array}$ & $\begin{array}{l}0 \\
0\end{array}$ & $\begin{array}{c}14.29 \% \\
(\mathrm{n}=1)\end{array}$ & $\begin{array}{l}0 \\
0\end{array}$ & $\begin{array}{l}0 \\
0\end{array}$ & $\begin{array}{l}0 \\
0\end{array}$ \\
\hline Metacarpal & $\begin{array}{c}5 \% \\
(n=7)\end{array}$ & $\begin{array}{c}23.68 \% \\
(\mathrm{n}=9)\end{array}$ & $\begin{array}{l}0 \\
0\end{array}$ & $\begin{array}{l}0 \\
0\end{array}$ & $\begin{array}{l}0 \\
0\end{array}$ & $\begin{array}{c}33.33 \% \\
(\mathrm{n}=1)\end{array}$ & $\begin{array}{l}0 \\
0\end{array}$ \\
\hline Lumbar & $\begin{array}{l}4.29 \% \\
(\mathrm{n}=6)\end{array}$ & $\begin{array}{l}0 \\
0\end{array}$ & $\begin{array}{l}0 \\
0\end{array}$ & $\begin{array}{l}0 \\
0\end{array}$ & $\begin{array}{l}0 \\
0\end{array}$ & $\begin{array}{l}0 \\
0\end{array}$ & $\begin{array}{l}0 \\
0\end{array}$ \\
\hline Mandible & $\begin{array}{l}3.57 \% \\
(\mathrm{n}=5)\end{array}$ & $\begin{array}{l}0 \\
0\end{array}$ & $\begin{array}{c}23.08 \% \\
(\mathrm{n}=3)\end{array}$ & $\begin{array}{l}0 \\
0\end{array}$ & $\begin{array}{l}0 \\
0\end{array}$ & $\begin{array}{l}0 \\
0\end{array}$ & $\begin{array}{l}0 \\
0\end{array}$ \\
\hline Phalanges & $\begin{array}{l}3.57 \% \\
(\mathrm{n}=5)\end{array}$ & $\begin{array}{l}0 \\
0\end{array}$ & $\begin{array}{l}0 \\
0\end{array}$ & $\begin{array}{l}0 \\
0\end{array}$ & $\begin{array}{l}0 \\
0\end{array}$ & $\begin{array}{l}0 \\
0\end{array}$ & $\begin{array}{l}0 \\
0\end{array}$ \\
\hline Metatarsal & $\begin{array}{l}2.86 \% \\
(\mathrm{n}=4)\end{array}$ & $\begin{array}{c}39.47 \% \\
(\mathrm{n}=15)\end{array}$ & $\begin{array}{l}0 \\
0 \\
\end{array}$ & $\begin{array}{l}0 \\
0 \\
\end{array}$ & $\begin{array}{l}0 \\
0 \\
\end{array}$ & $\begin{array}{c}66.67 \% \\
(\mathrm{n}=2)\end{array}$ & $\begin{array}{l}0 \\
0 \\
\end{array}$ \\
\hline SEX & & & & & & & \\
\hline Male & $\begin{array}{c}66.43 \% \\
(\mathrm{n}=93)\end{array}$ & $\begin{array}{c}23.68 \% \\
(\mathrm{n}=9)\end{array}$ & $\begin{array}{c}61.54 \% \\
(\mathrm{n}=8)\end{array}$ & $\begin{array}{l}\text { Could } \\
\text { not be }\end{array}$ & $\begin{array}{l}25 \% \\
(\mathrm{n}=1)\end{array}$ & $\begin{array}{l}0 \\
0\end{array}$ & $\begin{array}{l}100 \% \\
(\mathrm{n}=1)\end{array}$ \\
\hline Female. & $\begin{array}{c}33.57 \% \\
(\mathrm{n}=47)\end{array}$ & $\begin{array}{l}76.32 \% \\
(\mathrm{n}=29)\end{array}$ & $\begin{array}{c}38.46 \% \\
(\mathrm{n}=5)\end{array}$ & determined & $\begin{array}{l}75 \% \\
(\mathrm{n}=3)\end{array}$ & $\begin{array}{l}100 \% \\
(\mathrm{n}=3)\end{array}$ & $\begin{array}{l}0 \\
0\end{array}$ \\
\hline AGE & & & & & & & \\
\hline Less than 1 year & $\begin{array}{l}54.29 \% \\
(\mathrm{n}=76)\end{array}$ & $\begin{array}{c}36.84 \% \\
(\mathrm{n}=14)\end{array}$ & $\begin{array}{c}61.54 \% \\
(\mathrm{n}=8)\end{array}$ & $\begin{array}{l}\text { Could } \\
\text { not be }\end{array}$ & $\begin{array}{l}100 \% \\
(n=4)\end{array}$ & $\begin{array}{c}66.66 \% \\
(\mathrm{n}=2)\end{array}$ & $\begin{array}{l}0 \\
0\end{array}$ \\
\hline Above 1 year & $\begin{array}{l}45.71 \% \\
(\mathrm{n}=64)\end{array}$ & $\begin{array}{c}63.16 \% \\
(\mathrm{n}=24)\end{array}$ & $\begin{array}{c}38.46 \% \\
(\mathrm{n}=5)\end{array}$ & determined & $\begin{array}{l}0 \\
0\end{array}$ & $\begin{array}{c}33.33 \% \\
(\mathrm{n}=1)\end{array}$ & $\begin{array}{l}100 \% \\
(\mathrm{n}=1)\end{array}$ \\
\hline
\end{tabular}


Table.2 Incidence of dislocation, type of dislocation, Neurological affections, sex and age in different species

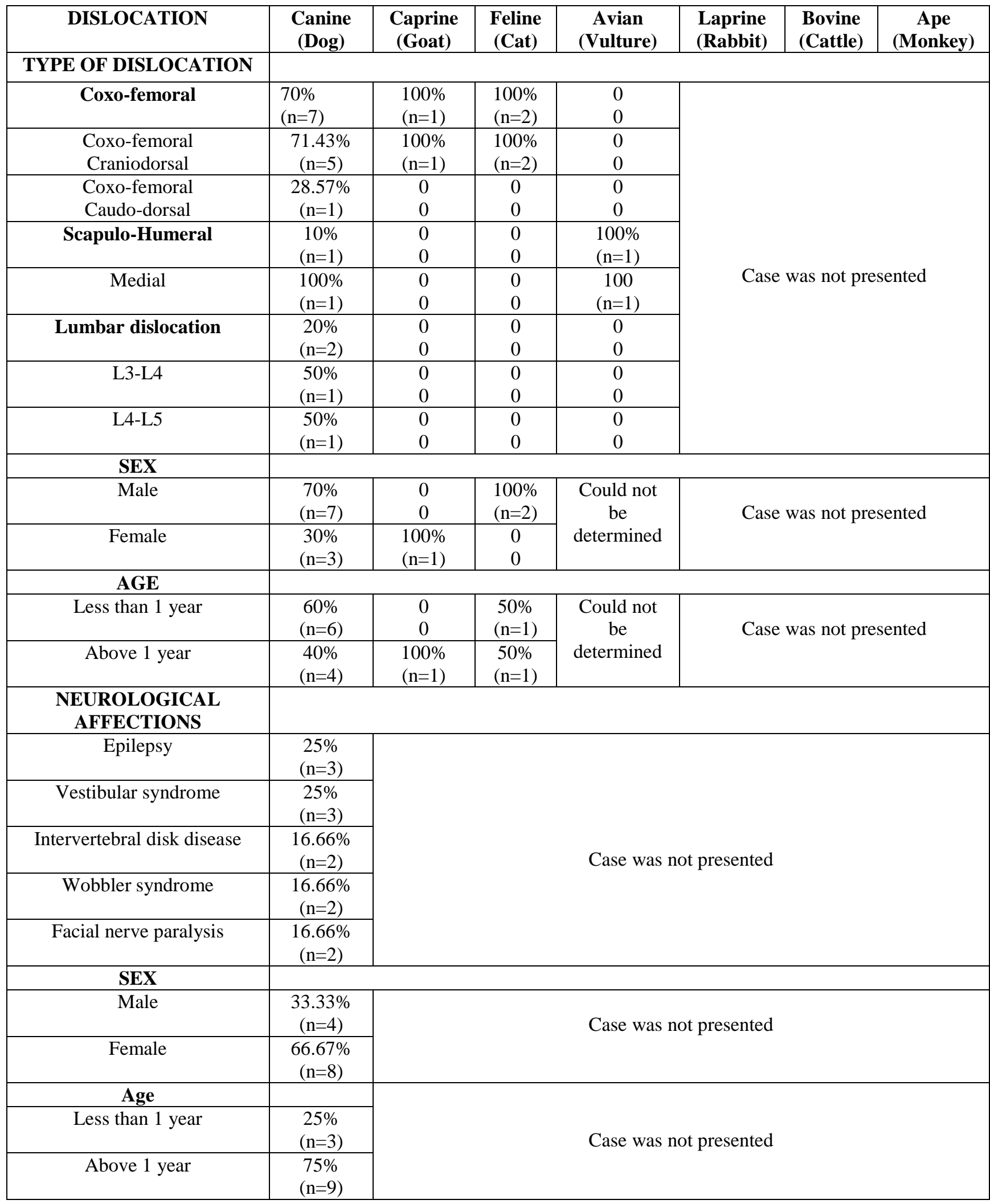


Fig.1 Incidence of fracture, dislocation and neurological affections

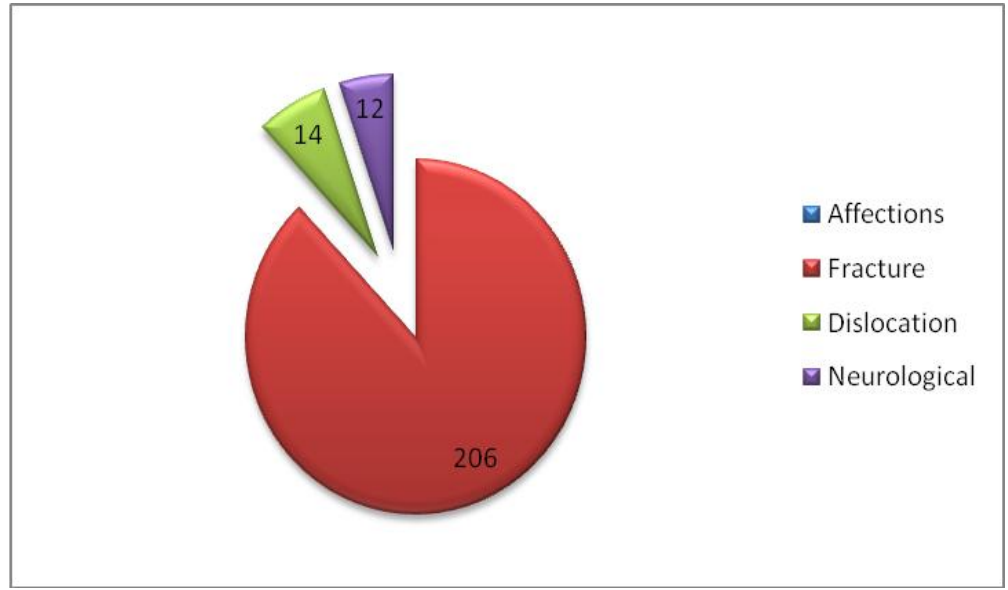

Fig.2 Incidence of fracture in different species of animals

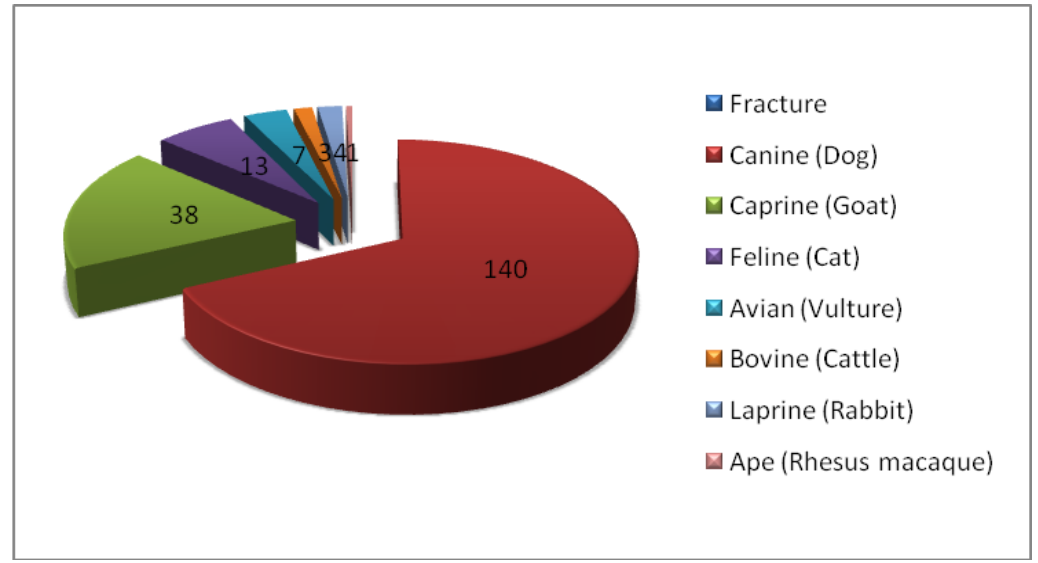

Fig.3 Incidence of dislocation in different species of animals

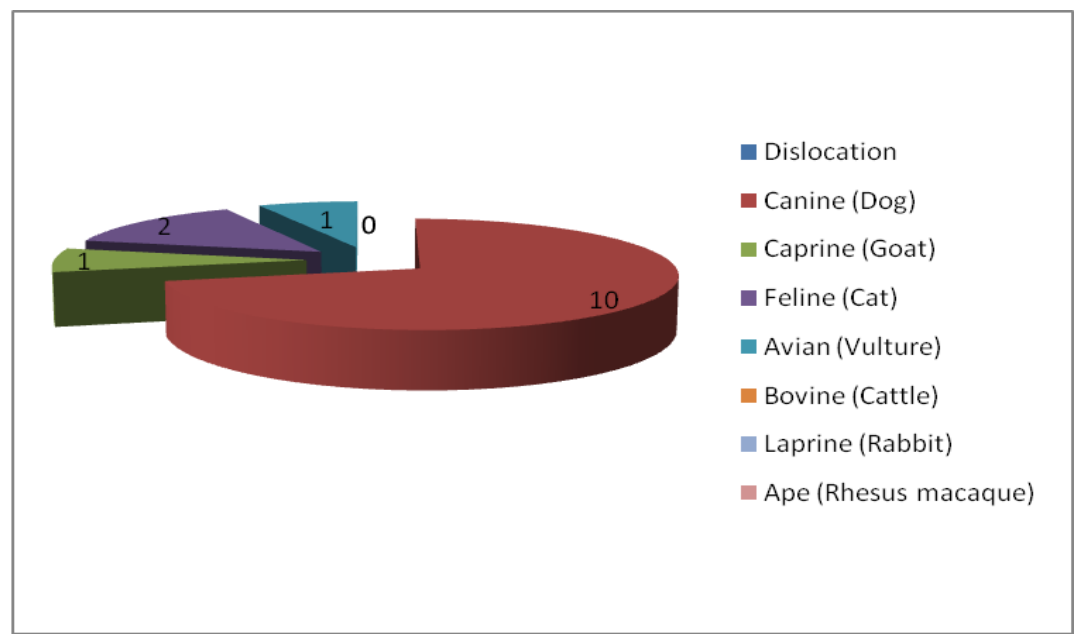


Fig.4 Breeds wise distribution of fracture incidence in dogs

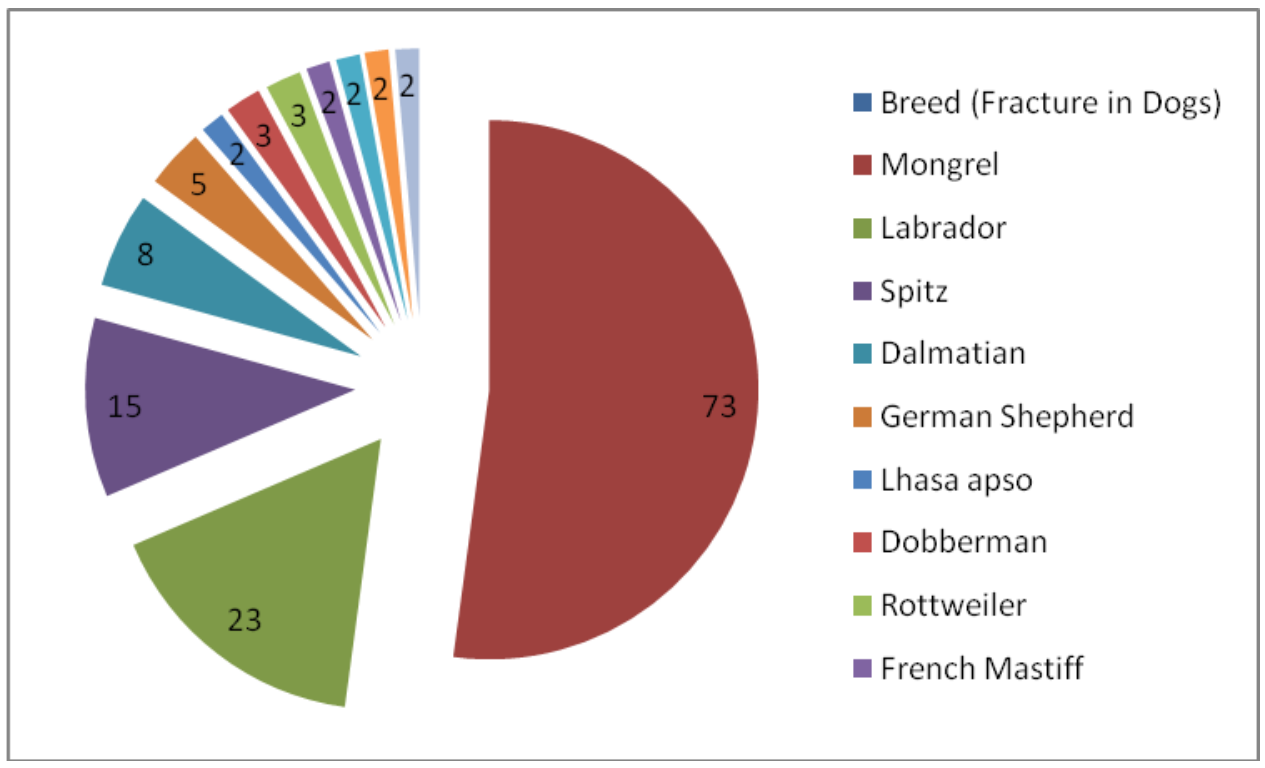

Fig.5 Incidence of bone involved in fracture of dogs

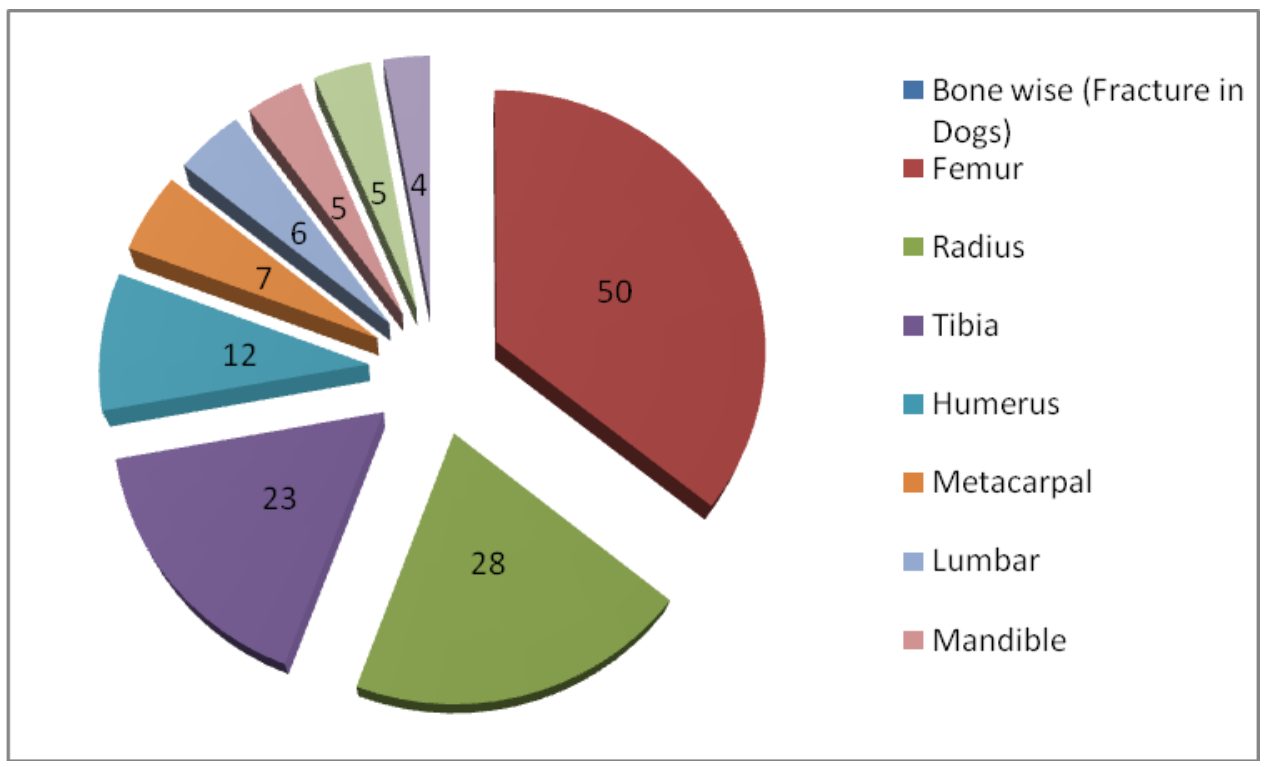

Fracture accounted higher in goat above one year of age $63.16 \% \%(n=24)$ as compared to below one year of age $36.84 \%(n=14)$ (Table $1)$. The higher incidence in these animals might be because they are more active in search of feed i.e. leaves and twigs, for grazing in hills or meet accident while crossing the road or while being chase by dogs. Among the bone, fracture incurred highest in metatarsal 39.47\% $(n=15)$ followed by metacarpal $23.68 \%(\mathrm{n}=9)$, tibia $18.42 \%$ $(n=7)$, radius $10.52 \%(n=4)$, humerus $5.26 \%$ $(\mathrm{n}=2)$, femur $2.63 \% \quad(\mathrm{n}=1) \quad($ Table 1$)$. Compound fracture accounted in $57.89 \%$ $(n=22)$ and closed fracture $42.11 \% \quad(n=16)$ (Table 1). The higher incidence of fracture in 
metatarsal bone and compound fracture might be because, the fracture occurred in bone having lower percentage of soft tissue covering for protection. Therefore making the bone vulnerable to lose its integrity and come out through the skin. Oblique fracture accounted in $31.58 \% \quad(\mathrm{n}=12)$, transverse fracture $26.31 \% \quad(n=10)$, multiple $26.31 \%$ $(n=10)$ and spiral fracture $15.80 \% \quad(n=6)$ (Table 1). The higher incidence of oblique fracture may be attributed to the predominance of bending or compression force (Newton and Nunamaker, 1985) acting on the bone of goat. Vehicular accident accounted in $86.84 \% \quad(n=33)$ cases of fracture, limb entangled in barbed wire 7.89 $\%(n=3)$, leg trapped in a pit hole $5.26 \%$ $(n=2)$. Higher incidence can be attributed to the increase in the number of motor vehicular accidents while in search of feed or while being chase by dogs in and around the suburban area.

Dislocation was noted in 1 case in goat (Table 2, Fig. 3). It occurred in Assam hill goat $(n=1)$, it might be due to breed preference or breed availability in urban and suburban area. Dislocation was observed in female $100 \%$ $(n=1)$, it can be attributed to the fact that female are more preferred due to economic contribution. It occurred in goat above 1 year of age. It might be due to the active nature of the animal in this group, while being in search of feed. Coxo-femoral dislocation (craniodorsal) was observed.

The higher incidence of coxo-femoral dislocation (cranio-dorasal) has been observed in other species i.e. canine (dog) (Newton and Nunamaker, 1985). Dislocation $100 \% \quad(n=1)$ was caused due to vehicular accident. This indicates, as these animals are in search of leaves and twigs for food make them more vulnerable to road traffic accidents and or fall from hilly slopes while being chase by the dog. Neurological affection was not reported.
In Feline (cat) 13 cases of fracture were recorded (Fig. 2). Fracture cases were recorded in Indian breed of cats $100 \%$ $(n=13)$, might be due to breed availability. Male accounted for highest incidence of fracture $61.54 \%(n=8)$ and female $38.46 \%$ $(n=5)$ (Table 1). It can be attributed to the fact that the male are more adventurous and loitering in nature therefore more prone to accidents. Fracture incidence were higher in cats less than one year of age $61.54 \%(n=8)$ followed by above one year of age $38.46 \%$ $(n=5)$ (Table 1). This might be due to the fact that the young animals are more active and have not learnt to cope with the hazard unlike their older counterparts (Kolata et al., 1974) and might become nervous or excited on seeing motor vehicles therefore become more prone to accident.

Femur was most commonly affected $46.15 \%$ $(n=6)$ followed by tibia $30.77 \% \quad(n=4)$, mandible $23.08 \%(n=3)$ (Table 1). The higher incidence of fracture in femur might be due to increased forces and momentum placed on proximal bones caused by physical factors such as muscle forces used for locomotion and resistance to the forces of gravity, ground reaction forces as limbs strike the ground and a long moment arm at the proximal aspect of limb compared with the distal portion of the limb (Markel et al., 1994) probably make them more susceptible to fracture. The findings correlate with previous study by Phillips (1979), Harasen, 2003, Elzomor et al., (2014). Closed fracture were seen in 53.85 $\%(\mathrm{n}=7)$ and compound fracture accounted for $46.15 \%(n=6)$ (Table 1). It might be due to the fact that fracture incurred in higher percentage in the bone which was under the thick belly of muscle preventing them to lose their integrity through skin. Oblique fracture accounted in $61.54 \% \quad(\mathrm{n}=8)$, transverse $23.08 \%(n=3)$ and spiral $15.38 \%(n=2)$ (Table 1). The highest incidence of oblique fracture may be attributed to the predominance of 
bending or compression (Newton and Nunamaker, 1985) force acting to break cat bone. For fracture incidence vehicular accident accounted for $84.62 \%(n=11)$, hit by owner with wooden stick $15.38 \% \quad(n=2)$. Vehicular accident has also been observed as the major cause of fracture in dogs and has been reported in previous study by Mala and cello, (1975), Philips (1979), Aithal et al., (1999).

Coxo-femoral dislocation (cranio-dorsal) was reported in 2 cases (Fig. 2). Coxo-femoral dislocation was recorded in Siamese cat $50 \%$ $(n=1)$ and Indian native breed of cat $50 \%$ $(n=1)$ (Table 2). Coxo-femoral dislocation was recorded in male cats $100 \%(n=2)$ (Table 2). Coxo-femoral dislocations was recorded in cats less than one year $50 \%(n=1)$ and above one year of age $50 \% \quad(n=1)$ (Table 2). Vehicular accident was the main cause of dislocation $100 \% \quad(n=2)$. Neurological affections were not reported in cat.

In Avian fracture were recorded in 7 cases (Fig. 2). The recorded cases were in vultures $(n=7)$. Fracture were recorded in Himalayan griffon $57.14 \%(\mathrm{n}=4)$ followed by White back $28.57 \%(n=2)$ and Slender bill $14.29 \%(n=1)$. Sex and age could not be determined. Bone wise distribution of fracture revealed highest incidence in fibula $42.85 \%(n=3)$ followed by ulna $28.57 \%(n=2)$, humerus $14.29 \% \quad(n=1)$ and femur $14.29 \% \quad(n=1) \quad$ (Table 1). Compound fracture were observed in $71.43 \%$ $(n=5)$ and closed fracture in $28.57 \%(n=2)$ (Table 1). Transverse fracture accounted $28.57 \%(\mathrm{n}=2)$, multiple $28.57 \%(\mathrm{n}=2)$, spiral $28.57 \%(n=2)$ and oblique in $14.29 \%(n=1)$ (Table 1). The incidence of fracture in vultures was due to accident by train.

Dislocation was recorded in 1 case. Dislocation was recorded in vulture $100 \%$ $(\mathrm{n}=1)$. It incurred in Himalayan griffon $100 \%$ $(n=1)$. Sex and age could not be determined.
Scapulo-humeral (medial) dislocation was recorded in vulture $100 \%(n=1)$ (Table 2). The cause of dislocation was accident by train. Neurological affection was not observed in vultures. In Laprine fracture accounted in 4 cases (Fig. 2). The recorded cases of fracture were in New Zealand white $100 \% \quad(n=4)$. Incidence of fracture were higher in female $75.00 \%(n=3)$ followed by male $25 \%(n=1)$ (Table 1). All the recorded cases $(n=4)$ of fracture in Laprine were in less than one year of age (Table 1). Compound fracture accounted in $50 \%(\mathrm{n}=2)$ and closed fracture $50 \%(n=2)$ (Table 1). Oblique fracture were seen in $50 \%(n=2)$ followed by spiral $25 \%$ $(n=1)$ and transverse $25 \%(n=1)$ (Table 1). Tibia appeared to be mostly affected $50 \%$ $(\mathrm{n}=2)$ followed by radius $25 \%(\mathrm{n}=1)$ and femur $25 \%(n=1)$ (Table 1$)$. The cause of fracture in these animal were entangled leg in cage $50 \%(\mathrm{n}=2)$, chase and caught by dog $25 \%(n=1)$ and entrapment of limb in between the door $25 \% \quad(n=1)$. Dislocation and neurological affections was not reported in laprine.

In bovine fracture was recorded in 3 cases $(n=3)$ (Fig. 2). Among the breed Holstein Friesan cross breed cattle accounted $33.33 \%$ $(n=1)$, Jersy cross breed $33.33 \%(n=1)$ and Assam indigenous cattle $33.33 \% \quad(n=1)$. Female accounted for all the fracture cases $100 \%(n=3)$ (Table 1). The higher incidence of fracture was observed in cattle less than 1 year of age $66.66 \%(n=2)$ followed by above 1 year $33.33 \%(n=1)$ (Table 1). Metatarsal fracture incidence were higher $66.67 \%(n=2)$ followed by metacarpal 33.33\% $(n=1)$ (Table 1). Compound fracture were seen in all the cases $100 \%(n=3)$ (Table 1). Multiple fracture were seen in $66.67 \% \quad(n=2)$ followed by transverse fracture in $33.33 \%(n=1)$ (Table 1). Cause of fracture included slipped and fell down $33.33 \% \quad(\mathrm{n}=1)$, vehicular accident $33.33 \%(n=1)$ and entrapment of the leg in draining pit $33.33 \%(\mathrm{n}=1)$. Dislocation and 
neurological affection was not reported in bovine.

In Ape fracture was recorded in 1 case $(n=1)$ $100 \%$ (Fig. 2). Rhesus macaque was affected with fracture. Fracture was recorded in male $(n=1)$ (Table 1). The animal was above 1 year of age (Table 1). Closed fracture was observed $(n=1)$ (Table 1). Radius was fracture $(n=1)$ (Table 1). Transverse fracture was observed $(n=1)$ (Table 1). Cause of fracture was inn fighting. Dislocation and neurological affection was not reported in ape.

\section{References}

Aithal, H.P., G.R. Singh and Bisht G.S. 1999. Fractures in dogs: A survey of 402 cases. Indian J. Vet. Surg. 20(1):15-21.

Balagopalan,T.P., C.B. Devanand, K. Rajankutty, T.S. Amma, S.R. Nayar, C.A. Varkey, A.M. Jalaluddin, K.N.M. Nayar and George P.O.1995. Fracture in dogs: A review of 208 cases. Indian J.Vet.Surg. 16(1):41-43.

Elzomor, S.T., E.M.E. Sheta, H.A. Farghali and Asour A.E. 2014. Prevalence of femoral fractures in dogs and cats. Journal of Egypt Vet. Med. Assoc. 74 (2):269-278.

Harasen, G., 2003. "A common long bone fracture in small animal practice-part 1". Canadian Vet. Journal. 44:333-334.

Hulse, D.A. and Aron, D.N. 1994. Advances in small animal orthopaedics. Compendium 16:831-832.

Kolata, R.J., N.H. Kraut and Johnston D.E. 1974. Patterns of trauma in urban dogs and cats: a study of 1000 cases. J. Am. Vet. Med. Assoc.164: 499-502

Maala, C.P. and Celo, E.M. 1975. A study on the anatomical locations, incidence and causes of fractures in dogs. Phillipine J. Vet. Med. 14:137-143.

\section{How to cite this article:}

Chandan Kumar Singh, Kushal Konwar Sarma, Dwijen Kalita, Bitupona Deuri and Parsha Jyoti Nath. 2017. Review on Fracture, Dislocation and Neurological Affections in Animals between April 2011 to March 2013 around the Urban and Suburban Area of Guwahati, India. Int.J.Curr.Microbiol.App.Sci. 6(7): 1540-1550. doi: https://doi.org/10.20546/ijcmas.2017.607.184 